
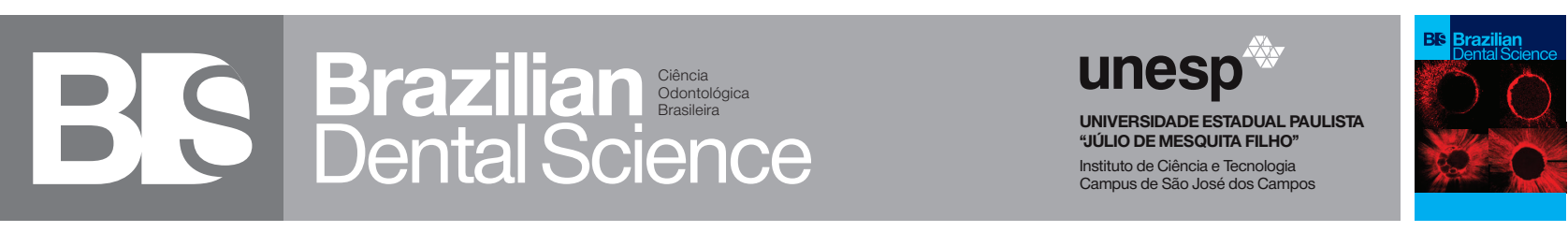

\title{
Assessment of alveolar bone level and furcation involvement in periodontal diseases using dental cone-beam computed tomography (CBCT): a systematic review
}

Avaliação do nível ósseo alveolar e envolvimento da furca em doenças periodontais usando a Tomografia computadorizada de feixe cônico odontológica: uma revisão sistemática

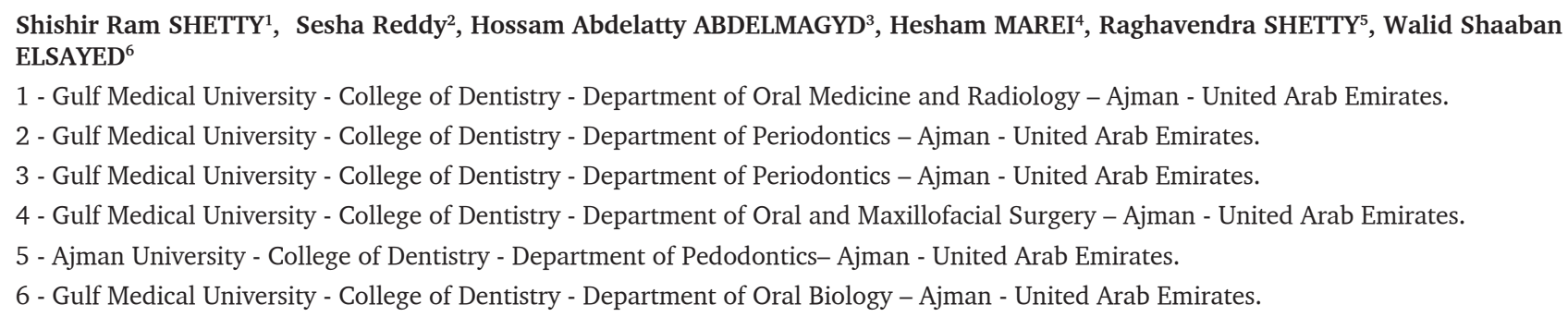

\begin{abstract}
The advent of CBCT has contributed significantly to dental imaging. In the field of periodontics, CBCT provides a multi-planar view to assess the alveolar bone in three dimensions. This helps the dentist to make measurements at any location that could significantly improve periodontal diagnosis. Objective: The aim of this systematic review is to evaluate the accuracy of using CBCT in the assessment of alveolar bone level and furcation involvement in periodontal diseases. Material and Methods: PubMed, LILACS and Google Scholar databases were searched for literature related to the application of CBCT in periodontal diseases. Keywords used for the search were CBCT, furcation involvement, measurement and their synonyms. Results: Fifteen full-text English language research papers were eligible for the systematic review using the PRISMA guidelines. Conclusion: From the results of the systematic review it can be concluded that conebeam computed tomography imaging technique offers significantly reliable images of the furcation involvement and height of the alveolar bone.
\end{abstract}

\section{KEYWORDS}

Cone Beam Computed tomography, furcation defects, alveolar bone loss

\section{RESUMO}

$\mathrm{O}$ advento da Tomografia computadorizada de feixe cônico (TCFC) contribuiu significativamente para a imageologia. No campo da periodontia, a TCFC fornece uma visão multiplano para avaliar o osso alveolar em três dimensões. Isso ajuda o dentista a fazer medições em qualquer local que possa melhorar significativamente o diagnóstico periodontal. Objetivo: O objetivo desta revisão sistemática foi avaliar a precisão do uso da TCFC na avaliação do nível ósseo alveolar e do envolvimento da furca em doenças periodontais. Material e Métodos: As bases de dados PubMed, LILACS e Google Scholar foram pesquisadas na literatura relacionada à aplicação da TCFC em doenças periodontais. As palavras-chave utilizadas para a pesquisa foram TCFC, envolvimento da furca, mensuração e seus sinônimos. Resultados: Quinze trabalhos de pesquisa em inglês com texto completo foram elegíveis para a revisão sistemática usando as diretrizes do PRISMA. Conclusão: A partir dos resultados da revisão sistemática, pode-se concluir que a técnica de imagem por tomografia computadorizada de feixe cônico oferece imagens significativamente confiáveis do envolvimento da furca e da altura do osso alveolar.

\section{PALAVRAS-CHAVE}

Tomografia computadorizada de feixe cônico; Defeitos de furca; Perda óssea alveolar. 


\section{INTRODUCTION}

P eriodontitis is the most commonly occurring oral disease characterized by alveolar decrease in alveolar bone height [1]. Assessment of the residual alveolar bone prior to periodontal therapy provides accurate information about the hard tissue morphology leading to a more precise formulation of treatment plan [2]. Radiography plays a vital role in diagnosis of periodontal disease since they reveal the hard tissue morphology, which is a key indicator of periodontal disease $[3,4]$. Conventionally periapical and panoramic radiographs were used to assess the periodontal hard tissue status with practically no or limited insight into buccal and lingual alveolar bone morphology [5]. The introduction of cone beam computed tomography (CBCT) into the field of dentistry aided in overcoming the limitations of conventional imaging [6]. The main advantage of CBCT is its ability to eliminate image distortions and provide effective visualization of the anatomical structures in in all three orthogonal planes $[7,8]$.

Recently, few clinical studies have been conducted using CBCT for determining the extent of periodontal hard tissue destruction have demonstrated positive results [9]. However a comprehensive review of such studies, taking into consideration factors such as diagnostic accuracy and precision was required. With this background a systematic review was conducted to evaluate the literature involving estimation of bony changes in periodontal disease using CBCT. The aim of our study review was to evaluate the results of clinical studies comparing CBCT based measurements of furcation dimensions with intra-surgical measurements.

\section{MATERIALS AND METHODS}

out based on (PRISMA) Preferred Reporting Items for Systematic Reviews guidelines [10]. An Internet based search was conducted using PUBMED, LILACS and Google Scholar databases. The keywords used for the search are listed in (Table I).

Table I - List of keywords used for manuscript search in scientific databases

$\begin{array}{|cc|}\text { Database } & \text { Search terms } \\ & \text { Cone Bean Computed Tomography, CBCT, Dental Volu- } \\ \text { metric Tomography, DVT, Dental Computed Tomography, } \\ \text { DCT, Cone Beam Tomography, CBT, C-arm CT, Cone Beam } \\ \text { Volume CT, Flat panel CT, Bone loss, Bone defects, horizon- } \\ \text { tal bone loss, bony defects, , intrabony defects, ,intrabony } \\ \text { crater, furcation involvement, one walled defects, two wal- } \\ \text { led defect, three walled defects, combined bony defects, } \\ \text { osseous defects, osseus crater, dehiscence, fenestration } \\ \text { hemiseptal defects measurement, assessment, reproduci- } \\ \text { bility, reliability, surgical measurement, precision }\end{array}$

The end search date was $2^{\text {nd }}$ June, 2019 across the databases. The selection process was conducted in two phases. In first phase, titles and abstracts from the selected electronic databases were reviewed by 2 authors.

\section{Inclusion criteria}

Clinical observational studies were included. Studies comparing CBCT measurements with the intra-surgical measurements of the periodontal bony defect and furcation involvement were included for the review. Clinical in vivo human studies published in English language was one of the criteria for the inclusion in systematic review.

This systematic review was carried 
Articles not full filling the inclusion criteria were excluded from the review. In phase 2, the full text articles obtained after filtering in phase 1 were evaluated by the same reviewers. In case of a disagreement in the selection process between the two reviewers, a third author was called in to reach a consensus. Details regarding authors, year of publication, sample size, number of examiners, type of evaluation method, type of periodontal parameter, and results were evaluated. In case of any relevant missing information the authors of the paper were contacted using email and the information was obtained.

\section{Exclusion criteria}

Studies published in any language other than English were not considered. Reviews, case reports, retrospective studies, letters and personal opinions pertaining to the topic were excluded from the systematic review. Studies that used other imaging techniques such as intraoral radiographs, panoramic radiograph and bitewing radiographs were not included in the review. Studies that did not compare the measurements from CBCT reconstruction to the reference standard were also not considered for the study. CBCT studies involving osseous healing after periodontal surgery, cleft palate repair, reconstructive osseous surgery and cleft palate surgery were not included in the study. CBCT studies involving the evaluation of alveolar bone in peri-implant region and orthodontics were not included in the study. The review did not involve studies carried out on CBCT evaluation of alveolar bone level in animals.

To evaluate the risk of bias at study level and at the outcome level as well as to determine the validity of the individual studies we have employed a checklist for assessing the studies used by Anter E et al.in their systematic review [11]. The checklist used in our study covered several aspects such as clarity of research question, definition of inclusion and exclusion criteria, adequacy of sample size, validity of clinical setting, adequacy of methods to eradicate bias.

\section{RESULTS}

The highlights of the search technique are mentioned in the flowchart. (Figure 1)

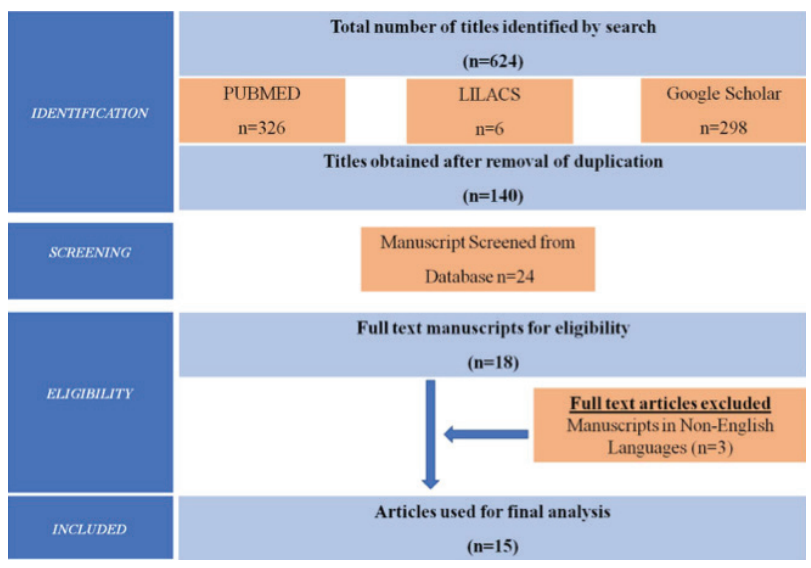

Figure 1 - Flowchart describing the steps in systematic review.

The database search revealed 624 articles which included 326 articles from PubMed, 6 from LILACS database and 298 from Google Scholar. After deleting the duplicate articles, 140 manuscripts were identified for the screening procedure. After a thorough review for eligibility only 15 full text English language articles qualified for the final systematic review. (Table II) 
Table II - Descriptive data of the eligible articles after initial identification and screening procedures

\begin{tabular}{|c|c|c|c|c|c|}
\hline $\begin{array}{l}\text { Authors } \\
\text { and year }\end{array}$ & $\begin{array}{l}\text { Sample size } \\
\text { and sites }\end{array}$ & $\begin{array}{l}\text { Number of } \\
\text { observers }\end{array}$ & Clinicalmeasurement tool & $\begin{array}{l}\text { Periodontal } \\
\text { parameter }\end{array}$ & Results \\
\hline $\begin{array}{l}\text { Pour GD et } \\
\text { al.2015(12) }\end{array}$ & 30 patients & Singles examiner & $\begin{array}{l}\text { Measurements done using a peri- } \\
\text { odontal probe during the surgery }\end{array}$ & $\begin{array}{l}\text { Alveolar } \\
\text { bone }\end{array}$ & $\begin{array}{c}\text { In the buccal, lingual/palatal, mesial and distal surfaces, no significant differ- } \\
\text { ence was observed between the values obtained using CBCT and the surgical } \\
\text { method }\end{array}$ \\
\hline $\begin{array}{l}\text { Qiao J et } \\
\text { al.2015(13) }\end{array}$ & $\begin{array}{l}15 \text { patients } \\
20 \text { sites }\end{array}$ & $\begin{array}{l}2 \text { examiners at } 1 \text { week } \\
\text { interval }\end{array}$ & $\begin{array}{l}\text { CAL measured using periodontal } \\
\text { probe graded in millimetres (PC- } \\
\text { PUNC-15; HU-Friedy, Chicago, IL, } \\
\text { USA). Nabers probe marked at } 3 \mathrm{~mm} \\
\text { intervals (PQ2N; HU-Friedy). }\end{array}$ & $\begin{array}{l}\text { Furcation } \\
\text { involvement }\end{array}$ & Intra-surgical findings confirmed $82.4 \%$ of the CBCT data. \\
\hline $\begin{array}{l}\text { Cimbaljevic } \\
\text { MM etal.2015 } \\
\quad(14)\end{array}$ & $\begin{array}{l}15 \text { patients } \\
174 \text { sites }\end{array}$ & $\begin{array}{l}\text { One examiner evaluated } \\
\text { the scant twice within a } \\
\text { gap of } 4 \text { weeks }\end{array}$ & $\begin{array}{l}\text { Evaluation of the furcation per- } \\
\text { formed using a Nabers probe (PQ2N, } \\
\text { Hu-Friedy }\end{array}$ & $\begin{array}{l}\text { Furcation } \\
\text { involvement }\end{array}$ & $\begin{array}{l}\text { Fl were more often detected by means of CBCT than by means of clinical } \\
\text { examination. Agreement between the evaluation methods was present in } \\
46.9 \% \text { of cases ( } 63.3 \% \text { in maxilla, } 45.0 \% \text { in mandible). FI detected clinically was } \\
\text { confirmed by means of CBCT in } 24 \% \text { of the evaluated sites. }\end{array}$ \\
\hline $\begin{array}{l}\text { Krantik et } \\
\text { al.2015(15) }\end{array}$ & $\begin{array}{l}17 \text { patients } \\
96 \text { furcation } \\
\text { sites }\end{array}$ & Single examiner & $\begin{array}{l}\text { Clinical measurements carried out } \\
\text { using Nabers probe marked at 3mm } \\
\text { intervals (HU-Friedy) }\end{array}$ & $\begin{array}{l}\text { Furcation } \\
\text { involvement }\end{array}$ & $\begin{array}{l}\text { Fl was observed in all } 96 \text { furcation entrances clinically, while a FI degree I-III } \\
\text { was found in } 75 \text { sites according to the CBCT. Overall, only } 28 \% \text { of the clinical } \\
\text { findings were confirmed in the CBCT, while } 30.2 \% \text { were overestimated and } \\
\qquad 41.7 \% \text { revealed an underestimation }\end{array}$ \\
\hline $\begin{array}{l}\text { Guo YJ et } \\
\text { al.2016(16) }\end{array}$ & $\begin{array}{l}6 \text { patients, } \\
150 \text { sites }\end{array}$ & 4 & $\begin{array}{l}\text { A manual periodontal probe (UNC-15; } \\
\text { HU-Friedy, Chicago, IL) graded in } \\
\text { millimetres was used }\end{array}$ & $\begin{array}{l}\text { Alveolar } \\
\text { bone loss }\end{array}$ & $\begin{array}{l}\text { No statistically significant difference was found between the surgical and } \\
\text { CBCT measurements ( } p=0.84) \text {. }\end{array}$ \\
\hline $\begin{array}{l}\text { Zhu Jet } \\
\text { al.2016 (17) }\end{array}$ & $\begin{array}{l}11 \text { patients } \\
\text { and } 39 \text { sites }\end{array}$ & $\begin{array}{l}\text { All images were analysed } \\
\text { twice by the same person, } \\
\text { with a time interval of more } \\
\text { than } 1 \text { week on the same } \\
\text { monitor under standard } \\
\text { conditions. }\end{array}$ & Nabers probe & $\begin{array}{l}\text { Furcation } \\
\text { involvement }\end{array}$ & $\begin{array}{l}\text { The parameters and related methods of measurements proposed in the study } \\
\text { showed high reproducibility. CBCT images provided more details in assessing } \\
\text { maxillary molar Fl. }\end{array}$ \\
\hline $\begin{array}{l}\text { Panjinigara } \\
\text { Netal.2016 } \\
\text { (18) }\end{array}$ & $\begin{array}{l}40 \text { patients } \\
200 \text { sites }\end{array}$ & $\begin{array}{l}\text { CBCT measurements and } \\
\text { clinical measurements } \\
\text { performed by two differ- } \\
\text { ent examiners }\end{array}$ & $\begin{array}{l}\text { Vertical component was measured } \\
\text { with Williams probe, } \\
\text { Horizontal component was mea- } \\
\text { sured with Nabers probe }\end{array}$ & $\begin{array}{l}\text { Furcation } \\
\text { involvement }\end{array}$ & $\begin{array}{c}\text { Pre-surgery clinical measurements (vertical } 6.15 \pm 1.71 \mathrm{~mm} \text { and horizontal } 3.05 \\
\pm 0.84 \mathrm{~mm} \text { ) and CBCT measurements (vertical } 7.69 \pm 1.67 \mathrm{~mm} \text { and horizontal } \\
4.62 \pm 0.77 \mathrm{~mm} \text { ) underestimated intra-surgery measurements (vertical } 8.025 \pm \\
1.67 \mathrm{~mm} \text { and horizontal } 4.82 \pm 0.67 \mathrm{~mm} \text { ) in both vertical and horizontal aspects, } \\
\text { and the difference was statistically not significant (vertical } \mathrm{P}=1.00 \text { ). }\end{array}$ \\
\hline $\begin{array}{l}\text { Padmanab- } \\
\text { han S et } \\
\text { al.2017(19) }\end{array}$ & $\begin{array}{l}14 \text { patients } \\
24 \text { sites }\end{array}$ & 1 & $\begin{array}{l}\text { intrasurgical measurements were } \\
\text { done using an endodontic file and } \\
\text { assessed with a digital vernier } \\
\text { caliper }\end{array}$ & $\begin{array}{l}\text { Furcation } \\
\text { involvement }\end{array}$ & $\begin{array}{c}\text { The CBCT versus intrasurgical furcation measurements were } 2.18 \pm 0.86 \mathrm{~mm} \\
\text { and } 2.30 \pm 0.89 \mathrm{~mm} \text { for furcation height, } 1.87 \pm 0.52 \mathrm{~mm} \text { and } 1.84 \pm 0.49 \mathrm{~mm} \\
\text { for furcation width, and } 3.81 \pm 1.37 \mathrm{~mm} \text { and } 4.05 \pm 1.49 \mathrm{~mm} \text { for furcation depth, } \\
\text { respectively. Results showed that there was no statistical significance between } \\
\text { the measured parameters, indicating that the two methods were statistically } \\
\text { similar }\end{array}$ \\
\hline $\begin{array}{l}\text { Aghanashini } \\
\text { Setal.2017 } \\
\text { (20) }\end{array}$ & $\begin{array}{l}\text { 22 patients } \\
50 \text { sites }\end{array}$ & $\begin{array}{l}\text { Clinical measurements } \\
\text { and image analysis } \\
\text { was done by } 2 \text { different } \\
\text { examiners }\end{array}$ & $\begin{array}{l}\text { Clinical measurements were done } \\
\text { with a Nabers probe }\end{array}$ & $\begin{array}{l}\text { Furcation } \\
\text { Involvement }\end{array}$ & $\begin{array}{l}\text { Thus, the results indicated that there was the highest agreement between } \\
\text { measurements obtained using CBCT imaging technique and true level of } \\
\text { involvement seen during OFS (89\%) when compared to clinical and OFS } \\
\text { measurements (11\%) and clinical and CBCT measurements (3\%). }\end{array}$ \\
\hline $\begin{array}{l}\text { Zhang Wet } \\
\text { al.2018(21) }\end{array}$ & 83 patients & $\begin{array}{l}\text { Single examiner evaluated } \\
\text { the cans } 2 \text { times within } 7 \\
\text { months }\end{array}$ & Periodontal probe and Nabers probe & $\begin{array}{l}\text { Furcation } \\
\text { involvement }\end{array}$ & $\begin{array}{l}\text { There were significant correlations ( } \mathrm{p} \text { « } 0.05) \text { between clinical detection and in- } \\
\text { traoral radiography, clinical detection and CBCT, as well as intraoral radiography } \\
\text { and CBCT at all the measured sites ( } r \text { values range between } 0.230 \text { to } 0.644) \text {. } \\
\text { CBCT exhibited higher correlation with clinical detection relative to intraoral } \\
\text { radiography, especially at distal palatal side of maxillary first molar ( } p<0.05 \text { ). }\end{array}$ \\
\hline $\begin{array}{l}\text { Parvez MF et } \\
\text { al.2018(22) }\end{array}$ & 17 subjects & Single examiner & $\begin{array}{l}\text { Clinical measurements performed } \\
\text { using curved Nabers probe marked } \\
\text { at } 3 \text { mm intervals }\end{array}$ & $\begin{array}{l}\text { Furcation } \\
\text { involvement }\end{array}$ & $\begin{array}{l}\text { There was no statistically significant difference between CBCT measurements } \\
\text { and surgical measurements }(p \leq 0.05) .\end{array}$ \\
\hline $\begin{array}{l}\text { Patil SRet al. } \\
2018(23)\end{array}$ & 32 patients & $\begin{array}{l}\text { Single examiner inter- } \\
\text { preted the images,and } \\
\text { each measurement } \\
\text { was repeated twice by } \\
\text { the same operator after } \\
\quad 15 \text { days }\end{array}$ & $\begin{array}{l}\text { All direct surgical measurements } \\
\text { were made with a probe (HU Friedy), }\end{array}$ & $\begin{array}{l}\text { intrabony } \\
\text { periodontal } \\
\text { defects }\end{array}$ & $\begin{array}{l}\text { No significant difference was noted regarding the CBCT measurements of } \\
\text { the facio-lingual width and M-D width of the defect when compared with the } \\
\text { measurements obtained during the surgical procedures. }\end{array}$ \\
\hline $\begin{array}{l}\text { Yang J etal. } \\
2019(24)\end{array}$ & 13 patients & 3 examiners & Periodontal probe & $\begin{array}{l}\text { Alveolar } \\
\text { bone }\end{array}$ & $\begin{array}{l}\text { Statistically significant differences were found between } C B C T \text { and } C A L+2.04 \\
\text { mm }(P=0.000) \text {, as well as intra-surgical evaluation }(P=0.001) \text {. All sites showed } \\
\text { differences in CBCT versus intra-surgical measurement and versus CAL }+2.04 \\
\text { comparisons, except the buccal sites }(P=0.187 \text { and } 0.147 \text {, respectively). }\end{array}$ \\
\hline $\begin{array}{l}\text { Sreih Retal. } \\
2019(25)\end{array}$ & 10 patients & One examiner & $\begin{array}{l}\text { Hard tissue measurements were } \\
\text { recorded by a periodontal probe } \\
\text { CP } 15 \text { UNC (HU-Friedy }{ }^{\circledR} \text {, Chicago, IL, } \\
\text { USA) accurate to the nearest 0.5mm } \\
\text { Furcation defects (FD) were as- } \\
\text { sessed using a curved Nabers probe } \\
\left.\text { (PQ2N, HU-Friedy }{ }^{\circledR}\right)\end{array}$ & $\begin{array}{l}\text { Marginal } \\
\text { bone levels } \\
\text { and furca- } \\
\text { tion involve- } \\
\text { ments }\end{array}$ & $\begin{array}{l}\text { Statistical significance was found between the modalities concerning linear } \\
\text { measurements. CBCT showed less bone loss while intrasurgical measure- } \\
\text { ments showed more bone loss. Furcation defects were similar between CBCT } \\
\text { and intra-surgical measurement }\end{array}$ \\
\hline $\begin{array}{l}\text { Nayyar AS et } \\
\text { al.2019(26) }\end{array}$ & 12 patients & One examiner & $\begin{array}{l}\text { It was measured using the standard } \\
\text { UNC } 15 \text { periodontal probe }\end{array}$ & $\begin{array}{l}\text { Bone } \\
\text { defects }\end{array}$ & $\begin{array}{l}\text { The CBCT measurements and clinical measurements for various sites in the } \\
\text { anterior and posterior teeth was found to be highly significant in all the cases } \\
\qquad(\mathrm{P}=0.001)\end{array}$ \\
\hline
\end{tabular}


On analysis of the data in the current review, we observed that the full text articles ranged from 2015 to 2019. The number of patients involved in the study ranged from a minimum of 10 patients in one of the studies to a maximum of 83 patients in another study. The number of examiners evaluating the clinical and radiographic measurements in these studies also showed variation. There were 9 studies with single observer. Four of the studies used 2 observers whereas 3 and 4 observers were used in one study each. Radiographic measurements of different periodontal parameters were evaluated in the studies. Furcation involvement was evaluated in 11 studies. Alveolar bone loss was evaluated in 4 clinical studies, whereas both furcation involvement and alveolar bone evaluation was carried out in one study. The clinical evaluation of the furcation area was carried out using Nabers probe in all the studies whereas the alveolar bone level measurements were carried out using periodontal probe (HU Friedy).

\section{DISCUSSION}

The application of CBCT in detection of periodontal bone levels has received significant importance in the past 5 years and the studies pertaining to this specific area of research have been reviewed systematically in three recent publications $[11,27,28]$. The numbers of full text articles found eligible for the review were 14, 16 and 13 in studies conducted by Anter E et al. , Haas LF et al. and Choi IG et al. respectively. $[11,27,28]$ In our systematic review 15 research studies were eligible for the final analysis. Anter E et al. used PubMed database whereas Haas LF et al. used LILACS, PubMed, Scopus and Web of Science. Choi IG et al. employed The MEDLINE and Embase databases for their article search $[11,27,28]$. In our systematic review we obtained articles from PubMed and Google Scholar. The detailed analysis of the results of the fifteen eligible articles in our review is presented under two broad subheadings, which are alveolar bone level evaluation and evaluation of furcation involvement.

\section{Alveolar bone level evaluation}

Pour GD et al. observed that there was no significant difference between the measurements using CBCT and the surgical method in the buccal, lingual/palatal, mesial and distal aspects of alveolar bone [12]. Similar results were obtained in a study conducted by Guo YJ et al. There was no significant difference $(\mathrm{p}=0.84)$ between intra-surgical surgical and CBCT measurements in Guo YJ et al's study. Another important observation in Guo's study was statistically insignificant inter-observer $(\mathrm{p}=0.95)$ and intra-observer $(\mathrm{p}=0.30)$ difference among the observers [16]. Intra-bony periodontal defects study by Patil SR revealed that there was no significant difference between the CBCT measurements and intra-surgical measurements.

However a contrast results were obtained in the study conducted by Yang $\mathrm{J}$ et al. They found statistically significant difference between CBCT and intra-surgical measurements $(\mathrm{P}=$ 0.001) [ 24].

Yang $\mathrm{J}$ et al. stated that there could be specific reasons for the results of their study contradicting the results of those studies advocating the application of CBCT in estimating periodontal bone levels. One of the reasons stated is that most of the studies only included the premolar and molar region but seldom involved the anterior region. A study conducted by $\mathrm{Mol}$ et al. demonstrated that CBCT has reduced accuracy in measurements especially in the anterior region of the jaw. [29]. This could be attributed to morphology of the periodontal bone and presence of thinner buccal and lingual plates in the anterior region of the jaws [29].

Furthermore, some researchers also stated that the accuracy of measurement of bone levels may also depend on type of CBCT equipment and resolution capabilities. It has been found that measurements from the $0.25-\mathrm{mm}$ resolution images will be significantly more accurate than the measurements from the $0.4-\mathrm{mm}$ resolution images [30].

Another reason for inconsistencies between intra-surgical clinical bone level measurements and CBCT measurements could be due to poor accessibility in certain areas particularly in the lingual and palatal aspects [31]. The inconsistencies of CBCT in determining bone levels especially in the palatal/lingual sites of anterior teeth was highlighted in a study 
conducted by Nayyar AS et al. [26] They found that in the anterior region the mean CBCT measurement value of $4.0444 \mathrm{~mm}$ and the mean intra-surgical value was $4.1822 \mathrm{~mm}$. The difference was statistically significant. However, there was no statistical difference between the CBCT measurements and intra-surgical measurements in the posterior teeth. Another aspect that is to be taken into consideration while employing CBCT for making alveolar bone level measurements is relatively higher radiation dose compared to intraoral periapical radiography or panoramic radiography [32].

\section{Evaluation of furcation involvement}

The main advantage of CBCT over the conventional two dimensional radiographic techniques is unobstructed multi-planar view of the anatomical structures. the multi-planar viewing is beneficial especially in the furcation areas (Figure 2).

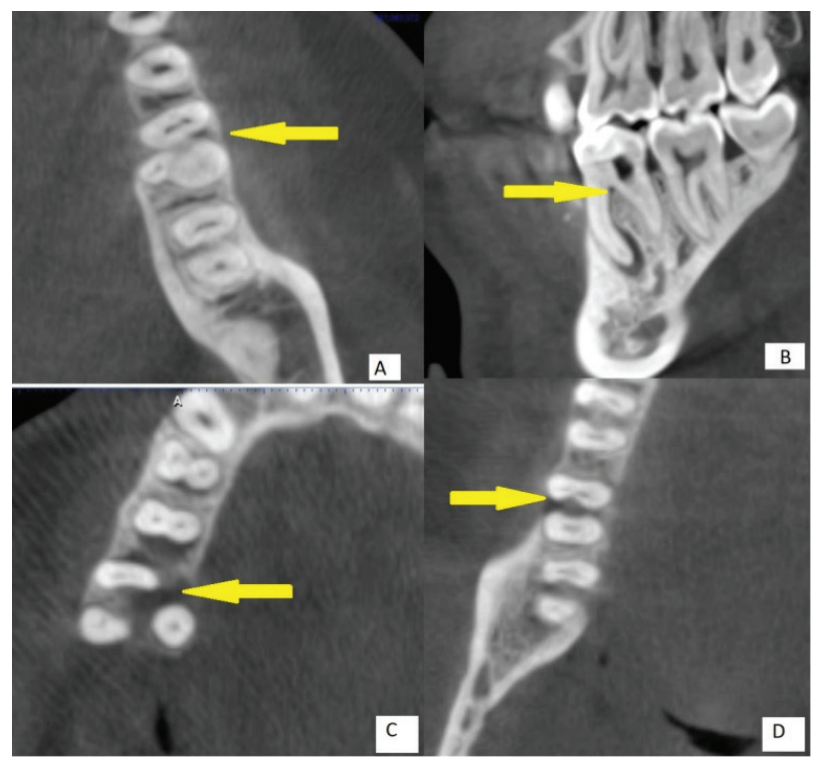

Figure 2 - (A) Axial CBCT section showing initial furcation changes in mandibular first molar. (B) Sagittal CBCT section showing Initial furcation changes with periapical lesion in mandibular first molar. (C) Axial CBCT section showing furcation involvement from the palatal aspect in the maxillary first molar. (D) Axial CBCT section showing advanced furcation involvement in mandibular second molar. (Image CourtesyShishir Shetty).
Qiao et al. concluded that the CBCT images demonstrated high accuracy in evaluating furcation involvement. Another important observation in this study was that the intra-surgical measurements were most consistent with CBCT measurements in the buccal furcation followed by disto-palatal and mesio-palatal furaction.[13] The results were similar to the one observed in the study by Walter et al. [33] But some studies have found different results regarding the accuracy of CBCT in matching up to clinical measurements in different types of furcation. In a study by Cimbaljevic MM et al. it was observed that the highest agreement between clinical probing and CBCT measurements (73.7\%) in furcation involvement detection was observed in the disto-palatal maxillary area. The lowest agreement $(36.6 \%)$ was found in the buccal areas of the mandibular molar [14]. However the difference could be attributed to the fact that the other studies were comparing the agreement between CBCT measurements and intra-surgical management, whereas the in the study by Cimbaljevic MM et al. the agreement between CBCT measurements and clinical probing was carried out for evaluating furcation involvement. Another study conducted by Cimbaljevic MM et al. it was observed that clinical experience and CBCT expertise had no major impact on detection of furcation involvement in CBCT scans, if the interpreter has received adequate training [34]. In another study conducted by Kranti K et al. , it was found that, just $28 \%$ of the clinical findings were confirmed during CBCT analysis. On the contrary $30.2 \%$ of CBCT measurements were overestimated and 41.7\%were underestimated when compared to clinical measurements [15]. The results of the study by Zhu $\mathrm{J}$ et al. revealed that CBCT scans were more efficient in assessing maxillary furcation involvement [24]. Specific furcal parameter investigated in the study included horizontal bone loss at furcation entrance level, maximum horizontal bone loss, maximum vertical bone loss and root trunk length. The accuracy of CBCT measurements were in furcation involvement was further reinforced by results obtained in studies conducted by Parvez MF et al. and Sreih R et al. $[22,25]$ In a study conducted by Aghanashini S et al. the furcation areas were grades from I-III during clinical, intra-surgical and CBCT 
assessment. This methodology was different from majority of studies, which tended to measure the dimensions of furcation involvement rather than grade the furcation defect [20]. The results of the study however was consistent with a majority of the studies with agreement of $(89 \%)$ between grading obtained using CBCT scans and intra-surgical procedures. The agreement between clinical and intra-surgical grading was (11\%) whereas the agreement between clinical and CBCT measurements was (3\%) [20].

\section{Intra-surgical measurements}

Endodontic file and assessed with a digital vernier caliper, Nabers probe and UNC 15 probe were the armamentarium used for the intrasurgical evaluation of periodontal defects in the clinical studies listed in our systematic review (12-26). While most of the researchers used Nabers probe and UNC 15 probe for measurement of bony defects Padmanabhan $S$ et al. used a combination of endodontic files and digital vernier caliper [19]. In their study the height of the defect was measured from the furcation fornix to the base of the alveolar base. The width of the defect was measured between the greatest dimensions of separation between the two roots above the crest of alveolar bone. the depth of the defect was measured from the crest of alveolar bone till the interradicular bony resistance was felt.

The authors stated that the digital vernier caliper had an accuracy of up to $0.2 \mathrm{~mm}$ and hence was preferred over other instruments. However the results of the above mentioned study was consistent with a majority of the other studies in which Nabers probe and UNC 15 probe to carry out the intra-surgical measurements. radiographic EXAMINATIONS DO NOT

\section{CONCLUSION}

Most of the research papers state that CBCT measurements are in agreement with intra-surgical alveolar bone measurements, however there is still some speculation regarding the accuracy of the measurements in the anterior areas with relatively thinner cortical areas. CBCT measurements were consistent with intrasurgical furcal measurements in most of the studies. However, there is evidence of some differences in areas, where accurate surgical measurements are difficult due to accessibility. Overall the efficiency of CBCT in detecting and evaluating furcation involvements remains significant however the radiation dose must be taken into account before advising for a CBCT scan in such clinical scenario.

In a recent guideline published by European Union study group on radiation protection it has been suggested that partial volume, high resolution CBCT may be indicated in only in selected cases of infra-bony defects, endo-perio lesions and furcation lesions. The guidelines stated that CBCT scans should be used in situations where clinical examinations and conventional radiographic assessment do not provide the adequate information needed for the treatment planning [35].

\section{REFERENCES}

1. Langen HJ, FuhrmannR, DiedrichP,Günther RW. Diagnosis of infra-alveolar bony lesions in the dentate alveolar process with high-resolution computed tomography: experimental results. Invest Radiol. 1995 Jul;30(7):421-6. doi:101097/00004424-199507000-00005

2. Leung CC, Palomo L, Griffith R, Hans MG. Accuracy and reliability of cone-beam computed tomography for measuring alveolar bone height and detecting bony dehiscences and fenestrations. Am J Orthod Dentofacial Orthop 2010 Apr; 137, S109-119. doi:10.1016/j.ajodo.2009.07.013.

3. Armitage GC. The complete periodontal examination. Periodontology 2000 2004;34:22-33. doi:10.1046/j.0906-6713.2002.003422.x

4. Bragger U. Radiographic parameters: biological significance and clinical use. Periodontology 2000. 2005; 39:73-90.doi:10.1111/.1.1600-0757.2005.00128.x

5. Bayat S, Talaeipour AR, Sarlati F.Detection of simulated periodontal defects using cone-beam CT and digital intraoral radiography. DentomaxillofacRadiol 2016 Jul; 45,20160030.doi: 10.1259/dmfr.20160030

6. Arai Y, Tammisalo E, Iwai K, Hashimoto K, Shinoda K. Development of a compact computed tomographic apparatus for dental use. DentomaxillofacRadiol 1999 Jul; 28: 245 8.doi: 101038/sj/dmfr/4600448

7. Ludlow JB, Davies Ludlow LE, Brooks SL. Dosimetry of two extraoral direct digital imaging devices: NewTom cone beam CT and Orthophos Plus DS panoramic unit. Dentomaxillofac Radiol 2003 Jul;32:22934. 9. doi:10.1259/ $\mathrm{dmfr} / 26310390$

8. Mah JK, Danforth RA, Bumann A, Hatcher D. Radiation absorbed in maxillofacial imaging with a new dental computed tomography device. Oral Surg Oral Med Oral Pathol Oral Radiol Endod Oct 2003;96:508 13.doi:10.1016/ s1079-2104(03)00350-0

9. Aljehani YA. Diagnostic applications of conebeam CT for periodontal diseases. Int JDent 2014;2014: 865079. doi: 101155/2014/865079.

10. Moher D, Liberati A, Tetzlaff J, Altman DG, The PRISMA Group (2009) Preferred Reporting Items for Systematic Reviews and Meta-Analyses: The PRISMA Statement. PLOS Med 6(7): e1000097.https://doi.org/10.1371/journal. pmed.1000097 
11. AnterE,Zayet MF,El-Dessouky SH. Accuracy and precision of cone beam computed tomography in periodontal defects measurement (systematic review). J Indian Soc Periodontol. 2016 May-Jun;20(3):235-243. doi: 10.4103/0972-124X.176389.

12. Pour DG, Romoozi E, Shayesteh YS. Accuracy of Cone Beam Computed Tomography for Detection of Bone Loss. J Dent TUMS 2015; 12(7) 513-523. PMID:26877741; PMCID: PMC4749417.

13. Qiao J, Wang S, Duan J, Zhang Y, Qiu Y, Sun C, Liu D. The accuracy of conebeam computed tomography in assessing maxillary molar furcation involvement. $J$ Clin Periodontol 2014 Mar; 41:269-274. doi: 10.1111/jcpe.12150.

14. Cimbaljevic MM, Spin-Neto RR, Miletic VJ, Jankovic SM, Aleksic ZM, Nikolic-Jakoba NS. Clinical and CBCT-based diagnosis of furcation involvement in patients with severe periodontitis. Quintessence Int 2015 NovDec;46:863-870.doi: 10.3290/j.qi.a34702

15. Kranti K, Mani R, Tervankar AR. Accuracy of Cone Beam Computed Tomography as a Pre-operative Tool to Assess Maxillary Molar Furcation Involvement. Int J Dent \& Oral Heal. 2015 Dec;(1):1-6. doi: 10.25141/2471-657X2015-1.0033

16. Guo Y-J,Ge Z-p, Ma R-h, Hou J-x, LiG. A six-site method for the evaluation of periodontal bone loss in cone-beam CT images. Dentomaxillofac Radiol 2016 Oct; 45:20150265. doi:10.1259/dmfr.20150265

17. Zhu J, Ouyang XY. Assessing Maxillary Molar Furcation Involvement by Cone Beam Computed Tomograph. Chin J Dent Res 2016 0ct;19(3):145-151.doi: 10.3290/j.cjdr.a36679

18. Pajnigara N, Kolte A, Kolte R, Pajnigara N,Lathiya V. Diagnostic accuracy of cone beam computed tomography in identification and postoperative evaluation of furcation defects. J Indian Soc Periodontol. 2016 Jul-Aug ;20(4): 386-390. doi:10.4103/0972-124X.192307.

19. Padmanabhan S, Dommy A, Guru SR, Joseph A. Diagnostic accuracy of cone beam computed tomography in identification and postoperative evaluation of furcation defects. Contemp Clin Dent. 2017 Sep; 8(3):439-445. doi:10.4103/ ccd.ccd 51517

20. Aghanashini S, Jayachandran C, Mundinamane DB, Nadiger S, Bhat D, Andavarapu S. Comparison of the Furcation Involvement by Clinical Probing and Cone Beam Computed Tomography withTrue Level of Involvement during Flap Surgery. World J Dent,2017 Jul;8(4):267-272. doi:10.5005/jpjournals-10015-1449

21. Zhang W, Keagan Foss K, Wang BY. A retrospective study on molar furcation assessment via clinical detection, intra oral radiography and cone beam computed tomography. BMC Oral Health 2018 May; 18:75 do: 10.1186/s12903018-0544-0

22. Parvez MF, Manjunath N, Kini R. Comparative assesment of accuracy of lopa and Cbct for maxillary molar furcation involvement: a clinical and radiological study. Int J Res Med Sci 2018 May;6:1765-9. doi: 10.18203/2320-6012. ijrms20181776.

23. Patil SR, Al-Zoubi IA, Gudipaneni R, Alenazi KK, Yadav N. A comparative study of cone-beam computed tomography and intrasurgical measurements of intrabony periodontal defects. Int J Oral Health Sci 2018 Jan;8:81-5. doi: 10.4103/ijohs.ijohs 1617.
24. Yang J,LiX, Duan D, Bai L, Lei Zhao L, Yi Xu Y.Cone-beam computed tomography performancein measuring periodontal bone loss. J Oral Sci 2019 Mar;61(1):61-66. doi:10.2334/josnusd.17-0332.

25. Sreih R, Ghosn N, Chakar C, Mokbel M, Naamn NB. Clinical and radiographic periodontal parameters: Comparison with software generated CBCT measurements.Int Arab J Dent 2019 Feb;10(1):10-18. Available at: http://ojs.usj. edu.lb/ojs/index.php/iajd/article/view/385.

26. Nayyar AS. Cone beam computed tomography and detection of periodontal bone defects in patients with advanced periodontal disease indicated for periodontal surgeries. Int J Head Neck Pathol 2018;:1:12-20. do: 10.4103/JHNP. JHNP 918.

27. Haas LF, Zimmermann GS, De Luca Canto G, Flores-Mir C, Corrêa M. Precision of cone beam CT to assess periodontal bone defects: a systematic review and meta-analysis. Dentomaxillofac Radiol 2018Feb;47:20170084 doi: 10.1259/ dmfr.20170084.

28. Choi IG, Cortes AR, Emiko Saito Arita ES, Georgetti MA Comparison of conventional imaging techniques and CBCT for periodontal evaluation: A systematic review. Imag Sci Dent 2018 Jun; 48: 79-86. doi: 10.5624/ isd.2018.48.2.79.

29. Mol A, Balasundaram. In vitro cone beam computed tomography imaging of periodontal bone. Dentomaxillofac Radiol 2008 Sep;37:319-324. doi:10.1259/ dmfr/26475758.

30. SunZ, Smith T, Kortam S, Kim DG, Tee BC, Fields H. Effect of bone thickness on alveolar bone-height measurements from cone-beam computed tomography images. Am J Orthod Dentofacial Orthop 2011 Feb; 139, e117-127. doi: 10.1016/j. ajodo.2010.08.016

31. Feijo CV, Lucena JG, Kurita LM, Pereira SL. Evaluation of cone beam computed tomography in the detection ofhorizontal periodontal bone defects: an in vivo study. Int J Periodontics Restorative Dent 2012 May-Jun; 32: e162-168. doi:10.4103/0972-124X.154176.

32 Roberts JA, Drage NA, Davies J, Thomas DW. Effective dose from cone beam CT examinations in dentistry. Br J Radiol 2009 Jan; 82: 35-40.doi: 10.1259/ bjr/31419627.

33. Walter C, Weiger R, Dietrich T, Lang NP,Zitzmann NU. Does threedimensionalimaging offer a financial benefit fortreating maxillary molars with furcationinvolvement? A pilot clinical case series. Clin Oral Imp Res. 2011 Mar; 23:351-358. doi: 10.1111/j.1600-0501.2011.02330.x.

34. Cimbaljevic M, Jankovic JM, Nikolic-Jakoba N. The Use of Cone-Beam Computed Tomography inFurcation Defects Diagnosis. Balk J Dent Med, 2016 Nov;20:143-148 doi: 10:1515/bjdm-2016-0023.

35. Directorate-General for Energy (European Commission). Radiation ProtectionCone beam CT for dental and maxillofacial radiology (Evidence-based guidelines). Luxembourg: EUROPA; published on 3rd July 2012. total pages 1542012. Reportnumber:172 doi-10.2768/21874.

\section{Dr Shishir Ram Shetty}

(Corresponding address)

Assistant Professor in Oral Medicine \& Radiology,

College of Dentistry, Gulf Medical University, Ajman, United Arab Emirates

Date submitted: 2019 Nov 02

E-mail: shishirshettyomr@gmail.com 